\title{
Transformational Leadership and Wealth Creation in Educational Organizations: The Case of Higher Education in Cameroon
}

\author{
Patience P. Teneng
}

\begin{abstract}
Education is a trillion-dollar industry, with a growing population thirsty for knowledge. There has been tremendous influx of graduates in this industry, seeking self-reliance because obtaining a decent job upon graduation remains a nightmare in developing countries. Consequently, the surroundings of state and private universities in Cameroon are overcrowded with educational subsidiary enterprises created by graduates. Most of these enterprises intend to metamorphose into giant self-reliant enterprises while mitigating the problem of graduate unemployment. This rarely happens as most of the enterprises end at ground level, while others close down in less than 5 years. A question arises: What prevents these small and medium-sized education businesses from thriving? This study surveyed 210 small and medium-sized educational firms selected through clustering technique. The SWOT analysis technique was used to determine the strengths, weaknesses, opportunities, and threats to these firms. Results revealed little or no leadership or wealth creation education as a major weakness, that threatens these businesses from thriving. The multiple regression further confirms the absence of transformational leadership education as a statistical predictor to setbacks in these firms. Key recommendations call for mainstreaming pragmatic transformational and strategic leadership education in higher education courses, using the case of the faculty of education of the University of Yaoundé I. Learners should be introduced to the world of business through meaningful partnership with the world of work and quality entrepreneurship courses.
\end{abstract}

Keywords: Strategic leadership, Transformational leadership, Wealth creation, Educational enterprises

\section{Introduction}

Education is more than a trillion-dollar industry which is booming, maybe because of a growing global population with a keen thirst for knowledge. But the question of how well today's universities prepare students for an uncertain future of work constitutes the prime concern for this industry. The nature of the education industry is extremely specific as compared to other tangible and non-tangible commodity markets. This is so because human beings are at the center of every action, constituting the major input, being at the center of the processing, and as end products as well. Thus, a school cannot be managed like a super market. Individuals intending to, or already into the supply of education and training are required to possess relevant entrepreneurial skills in educational leadership. The European Commission (2013) views this type of leadership as educational experts with the ability to concieve,

Full listing of authors and contacts can be found at the end of this article. design, plan and operate an educational project with significant impacts on participants. These experts should be skilled to significantly link education and the economic development of the nation as well. They should hold profiles of teachers, planners, inspectors in education, school curriculum designers, school administrators, managers, educational leaders, to name a few. The success of every business, including educational enterprises, requires the possession of entrepreneurial skills. Among these skills are wealth creation skills which are crucial for a well-grounded and sustained growth of enterprises. In this connection, the rapid rise and fall of small and medium-size enterprises in most countries around the world has been blamed on leadership lapses. This was confirmed in a study by the Canadian government in 2001 cited in Rowe (2001), which revealed that two important reasons why small and medium size firms become bankrupt and close down are poor overall management skills and imperfect capital structures. The poor management skills include lack of

Published by the Global Insitutute of Transformative Education (http://www.gite.education)

(c) Teneng. P. P. 2020. Open Access This journal is distributed under the terms of the Creative Commons Attribution

NonCommercial NonDerivative 4.0 International License (http://creativecommons.org/licenses/by-nc-nd/4.0/), which permits unrestricted use, distribution, and reproduction without revision in any non-commercial medium, provided you give appropriate credit to the original author(s) and the source, provide a link to the Creative Commons license, 
knowledge, lack of vision, and poor use of outside advisers. The imperfect capital structures result from either institutional constraints or lack of experience in management. The same study concluded that the way forward is effective leadership skill courses comprising of wealth creation skills, financial training and strategic leadership skills.

A study carried out by the National Institute of Statistics (2019) between 2009 and 2016 showed that the problem is compounded in Cameroon, revealing shocking figures on the premature sinking of small and medium-sized enterprises. According to this report published in March 2019, 96\% of sinking enterprises are small and medium-sized as against $04 \%$ of huge firms, with a total of 2, 316 enterprises that disappeared in this period. However, the report did not extend its reach to capture statistics on specific domains which could perhaps provide information on the state of education enterprises. An important note by this report was that only enterprises formally registered were sampled amidst an explosion of unregistered firms, particularly around the urban cities. Alternatively, this paper investigates private (non-government) formal and non-formal enterprises alike which are specifically involved in education and training activities (general teaching, technical and vocational training, writing, consulting enterprises, those in charge of preparing individuals for competitive entrance exams into public service jobs, study abroad issues, and language proficiency tests). The study by the National Institute of Statistics (2009) also highlighted aspects of human capital (education and training, experience, age and sex), which are of prime interest in this paper. Field statistics in this paper demonstrate high lapses in leadership skills (entrepreneurship, management, wealth creation skills) by those running these small and medium-sized education businesses in Yaoundé. Simply put, a considerable number of CEOs, administrators, and personnel running these small education enterprises confirmed to have acquired university education with no relevant entrepreneurship programs embedded. Graduates with certificates in education revealed that their involvement in educational business does not tie with their initial career objectives to occupy positions in public service, because of the prevailing unemployment situation in the country. According to NGU \& Teneng (2020), 4.2\% of the active labor force is currently unemployed. The underemployment situation is estimated at 7 on 10 individuals (71.75\%). This is more acute in rural areas with 78.8\% and $57.4 \%$ in urban centers (Cameroon, 2010, 44).
These authors also held that even though the public service has been able to absorb over 500,000 Cameroonians in the past years, the problem of graduate unemployment continues to be a call for concern because of the overwhelming number of unemployed graduate youths. The billion and one-dollar question is: What will become of these ready-to-work graduate youths in the face of limited job opportunities in the country? Most of them resort to the creation of educational enterprises for subsistence with the hope of growing them to bigger firms. Yet their efforts are short lived because their enterprises cannot stand the test of time. As these enterprises close down, their owners complain that their university education did not equip them with graduate skills for wealth creation or finding work in the private sector. The consequences are glaring as these entrepreneurs affirmed that their businesses are limited to the provision of daily bread, and nothing more. Others only operate seasonally when competitive entrance exams into public service jobs are launched. This is a peak period for such businesses when many candidates come seeking for preparatory classes in order to succeed in these exams. During interviews with the owners of these businesses, they revealed that majority of their businesses die off within a year. Based on such a morose situation, non-educational business men with very little or no mastery of the dynamics of the education sector have hijacked the educational enterprise for their capitalist gains. This demonstrates the failure of education faculty in higher education to impart the right skills for their learners to become strategic/transformational leaders in the educational enterprise. This is happening at a time when the future of education seems to be undergoing a paradigm shift into the fourth industrial revolution where technology is transforming how we live, work, play and think, making the problem of lack of skills more serious. According to (World Bank, 2019),

a wide range of occupations will require a high degree of cognitive abilities, such as creativity, logical reasoning and problem sensitivity as part of their core skill set. More than half of these do not yet do so today or only to a much smaller extent.

Today's education systems should equip youths with quality skills to thrive in tomorrow's world. Any continuous failure by today's educational systems to arrest this disastrous situation wil permanently allow education into the hands of these capitalists whose 
main objective is monetary gains, there by returning the status of human beings to machines as was the case at the heart of the 18th century industrial revolution. In Cameroon for example, most schools in the private sector are owned by non-educational businessmen, who sometimes employ teachers with tertiary certificates in education to teach in the classrooms, and sometimes serve as administrators for minimal wages. This raises the question of why educators are not leading in the educational enterprise? Why have they simply remained employees and not employers in the educational enterprise? The small and medium sized educational businesses created by some educators such as capacity building training centers, rural education networks, evening schools, multi-education services and consulting firms have remained at ground levels. As a result, the economic condition of this category of persons has remained wanting.

This work set out to investigate the extent to which education and training at the faculty of education in the University of Yaoundé I equips graduates with strategic/transformational leadership skills that can lead to wealth creation and sustainably enhance the growth of the education industry. To do this, the following research questions have been formulated to guide the study:

\section{Research Questions:}

1. To what extent does a university teaching (policy) influence the existence of a well-grounded wealth creation plan in educational enterprises in Cameroon?

2. To what extent does university curriculum content influence strategic/transformational leadership of graduates (wealth creation skills) in educational enterprises?

3. What is the relationship between teaching-learning models and graduates' strategic/transformational leadership skills (wealth creation) in educational firms?

4. What is the impact of mainstreaming modes of entrepreneurial education model in the faculty of education on leadership in educational firms?

\section{Conceptual literature}

Leadership - The concept of leadership has been a crossroad of intellectual and pragmatic flexing among CEOs, researchers, writers, politicians, civil society activists, and the list is inexhaustable. Some experts believe leadership means making a difference and transforming situations that seemed impossible, (Rowe, 2001). To others like Fonkeng and Tamanjong (2009), it is the ability of a manager to influence subordinates to voluntarily make efforts towards achieving organizational goals. These authors insist on the fact that personal skills and social attributes are crucial for leaders to succeed in an organization.

According to Farant (1980), the use of the concept 'leadership' without tying it to a specific domain or activity seems more confusing. This author explains that leadership skills are quite specific to context, though some common variables can be observed relating to the overall success of the organization. In this light, we can make mention of a religious leader, political leaders, CEO of a car manufacturing industry, the leader of a development and cultural association, the school principal, and the list is long. In relation to the leadership type that concerns this study (strategic/ transformational leadership in education or educational leadership), Bush and Glover (2012) define it as:

"... a process of influence, leading to the achievement of desired purposes. It involves inspiring and supporting others towards the achievement of a vision for the school which is based in clear personal and professional values".

However, the concept of leadership has evolved based on the functions, actions, risk taking, scope of interactions, and the targets they are expected to meet with specified time limits. Based on this, various conceptualizations like strategic leadership, managerial leadership, visionary leadership, transformational leadership, and transactional leadership have taken center stage in this debate. A clearer explanation of these concepts is presented below.

Managerial leadership - These are leaders concerned with the day-to-day running of the organization. To Fonkeng and Tamanjong (2009), managerial leadership simply means getting things satisfactorily done with a tactful use of available resources. This means that managers are more concerned with the manipulation of existing resources (human, material, and financial) so as to meet organizational goals. In the same light, Rowe (2001) asserts that managerial leaders may influence just the actions and decisions of those with whom they work. To him, they possess expertise in the operational and functional areas of the enterprise. However, they may make decisions that are not value-based. This does not mean that they are not

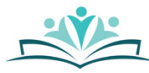


ethical and professional, but that they are rather under pressure to meet performance standards, thus limiting their scope of action. The observation in the past years is that managerial leadership has failed woefully in their tasks, as poor management decisions have rather destroyed organizational resources. This is true for the educational industry in Cameroon as small and medium sized educational firms have hardly survived a five years' infancy span, (National Institutes of Statistics, 2019). This discourse does not imply that this type of leadership is not needed in an enterprise. It is to rather inform readers that competent managerial leaders can only maintain existing wealth in a firm, but can hardly create any.

\section{Visionary Leadership}

In recent years, visionary leadership has been touted to be a preferred leadership option for most firms, including educational institutions. It is concerned with future orientations and risk-taking of the firm. In this direction, Rowe (2001) contends that this type of leadership maintains organizational control via socialization and fixed set of norms. It follows that visionary leadership deals with the inspirational component of transformational leadership. This confirms the fact that visionary leadership, though considered by some as mare dreaming for the future, is required for the future viability of the firm. However, an enterprise under such leaderships without strong managerial leadership accompanying it is liable to a down-to-earth failure. In this light, some experts posit that education leaders are not visionary, for they may be unable to provide even a five-year plan for their schools. This means they are limited to managerial leaders. Thus, they may need to consult the expertise of visionary leaders in order to better po-sition themselves for future trends and threats amidst the absence of a grounded strategy to arrive at long-term or future targets. To say that visionary leaders may forecasts the future correctly, but lack a pragmatic realization strategy to meet these future challenges. But a major lapse with these leaders is that they are more disordered in maintaining present financial stability of the firm.

\section{Strategic and Transformational Leadership}

Managerial leadership - These are leaders concerned with the day-to-day running of the organization. To Fonkeng and Tamanjong (2009), managerial leadership simply means getting things satisfactorily done with a tactful use of available resources. This means that managers are more concerned with the manipulation of existing resources (human, material, and financial) so as to meet organizational goals. In the same light, Rowe (2001) asserts that managerial leaders may influence just the actions and decisions of those with whom they work. To him, they possess expertise in the operational and functional areas of the enterprise. However, they may make decisions that are not value-based. This does not mean that they are not ethical and professional, but that they are rather under pressure to meet performance standards, thus limiting their scope of action. The observation in the past years is that managerial leadership has failed woefully in their tasks, as poor management decisions have rather destroyed organizational resources. This is true for the educational industry in Cameroon as small and medium sized educational firms have hardly survived a five years' infancy span, (National Institutes of Statistics, 2019). This discourse does not imply that this type of leadership is not needed in an enterprise. It is to rather inform readers that competent managerial leaders can only maintain existing wealth in a firm, but can hardly create any.

\section{Visionary Leadership}

In recent years, visionary leadership has been touted to be a preferred leadership option for most firms, including educational institutions. It is concerned with future orientations and risk-taking of the firm. In this direction, Rowe (2001) contends that this type of leadership maintains organizational control via socialization and fixed set of norms. It follows that visionary leadership deals with the inspirational component of transformational leadership. This confirms the fact that visionary leadership, though considered by some as mare dreaming for the future, is required for the future viability of the firm. However, an enterprise under such leaderships without strong managerial leadership accompanying it is liable to a down to earth failure. In this light, some experts posit that education leaders are not visionary, for they may be unable to provide even a fiveyear plan for their schools. This means they are limited to managerial leaders. Thus, they may need to consult the expertise of visionary leaders in order to better position themselves for future trends and threats amidst the absence of a grounded strategy to arrive at longterm or future targets. To say that visionary leaders may forecasts the future correctly, but lack a pragmatic realization strategy to meet these future challenges. 
But a major lapse with these leaders is that they are more disordered in maintaining present financial stability of the firm.

Strategic leadership comes from the Greek word strategos, meaning a general in command in the army, which later evolved by $450 \mathrm{BC}$ to include managerial skills, leadership, oratory and power. By $350 \mathrm{BC}$, it evolved to mean the ability to employ forces to defeat opposing forces, and to develop a unified system for global governance, (Rowe,2001). This concept is used in this study to have the same meaning as transformational leadership. This author further explains that strategic leadership is the most preferred type by most organizations today, as it has repeatedly resolved the lapses contained in other forms of leaderships including transactional leadership, managerial and visionary leaderships alike. Strategic leadership maintains shortterm operations and financial stability, while devising a grounded strategy for success in future bargains. This means that the strategic leader understands the emergent strategy process considered very important in organizational performance as compared to planning. It is also referred to as entrepreneurial leadership in education in this study and is used to describe individuals who have been equipped with relevant skills in the domain of education to be able to initiate, create, and run education businesses with commendable success.

According to Burns (1978), cited in Odumeru \& Ifanyi (2013), Transformational leadership has been recently introduced. These authors further maintained that:

"Transformational leadership enhances the motivation, morale, and performance of followers through a variety of mechanisms. These includes connecting the followers' sense of identity, and self to the project, and collective identity to the organization; being a role model for followers that inspires them, and makes them interested; challenging followers to take greater ownership for their work, and understanding the strengths and weaknesses of followers, so the leader can align followers with task that enhance their performance". (Odumeru \& Ifanyi, 2013, p. 356).

To Robins and Coulter as cited by Odumeru \& Ifanyi (2013), a transformative leader is someone who creates positive change in followers, and in the organization. They pay attention to developmental issues of the organization, stimulate and inspire followers to approach old problems in a new way. They have the continuous appetite to take the organization to another level, and giving it a better look as before(transform). Strategic leadership and transformational leadership have the same goals to meet, to take the organization to another level, and prepare it to overcome future challenges. It is for this reason that both leadership styles aim to perform above expected standards, maintain the present state of the firm, while working for heavy future achievements.

However, transformational leadership slides a bit from strategic style in that it is strongly tied to totally changing both the inner and outer look of the organization, whereas strategic leadership may be satisfied with an internal sustainable growth of the firm. Transformational leadership works more with followers transformed by the leaders themselves to hit defined targets, while strategic leaders better manage existing human resources to hit defined targets. However, the domain of education needs more of transformational leadership, since the inputs, machines, and outputs are human beings. Therefore, significant transformation is required, so to prepare key, and support staff to meet organizational goals more than expected.

\section{Transformational Leadership and Wealth Creation}

The concept of wealth creation in enterprises simply means securing sustainable financial resources, quality human and innovative infrastructural resources that will keep the enterprise growing in an upward trend for the present and for the future. Linking this to leadership can better be understood via the paradox of leading and managing per se. Rowe (2001) contends that wealth creation is at its best in enterprises with transformational leadership because these leaders make appropriate investments for viable future bargains, while maintaining the present financial state appropriately. These leaders have the skills to influence a critical mass of managers and personnel to make essential decisions that enhance stability in the daily operations of the enterprises, and for future viability as well. On the side of pure visionary leadership, the creation of wealth is faced with much difficulty as there is lack of an emergent strategy, or what is known as a pragmatic plan towards future viability of the firm. This type of leadership is poised with significant disorder in maintaining present stability of the firm. It falls squarely with the logic that "a vision without transformative strategy makes no sense, unlike a strategy without action is worse than zero." Some schools of thought confirm the above, maintaining that enterprises can still flourish 
with managerial leadership given they are well trained with transactional and transformational skills. Authors like Bass \& Bass Bernard, (1985) and Yuki, (1994), think that transactional leaders manage, while transformational leaders lead. Thus, transaction and transformation are two sides of the same coin: to manage and to lead. In this light, transactional leadership means ensuring the day-to-day running of the enterprise through the motivation, reward and punishment of workers, whereas transformational leadership prepares strong grounds for the enterprise to face future challenges.

However, transformational leadership has evolved a lot in relation to wealth creation since all other forms of leadership or leadership characterizations are inherent. Transformational leadership is thus a contingency model as it encompasses all other forms of leadership as seen above. In the educational domain, as in this study, most of the graduates who own businesses are the ones running their institutions. The sluggish growth, stagnation and probable closure of these enterprises demonstrates lapses in their higher education training, which surely failed to equip them with transformational leadership skills.

\section{Related Literature}

\section{Transformational Leadership in Higher Education}

Educational institutions have always craved for adaptive changes in order to respond to the demands of the job market. This phenomenon dates back from the industrial revolution, when industries dictated and controlled education and training dynamics to their benefit. It was in this light, Davies \& Davies (2004) insisted on the urgent need for transformational educational leaders as they explained in a 9-point memorandum which encompasses organizational abilities and individual abilities as seen below:

1. Strategic leaders have the following abilities:

- Be strategically oriented

- Translate strategy into action

- Align people and organizations

- Determine strategic intervention points

- Develop strategic competencies

2. Strategic leaders have the following personal characteristics:

- Dissatisfaction, restlessness for the present

- Absorptive capacity

- Adaptive capacity

- Wisdom
This author concludes that any other leadership components are incorporated in the scope of strategic leadership, hence making it the ideal type needed by schools to survive and sustain the turbulence of today's environment. Also, Davies \& Ellison (1997) explained that the dynamic of the 21st Century knowledge economy poses great fears for an uncertain future, as the world is moving into the fourth industrial revolution. School leaders must anticipate this uncertainty and device strategic action plans to train graduates to face the future volatile labor market. In relation to this study, starters and administrators of small education businesses need such skills so as to think and act big for a sustained growth of their enterprises. This will significantly step up livelihoods, employment, and the economy.

\section{Theoretical considerations}

A multitude of leadership theories have animated the discourse about which is the best to be used in what type of organization? Also, the debate of how to train in higher education for graduates to be equipped with specific leadership skills has been central as well. Theories like bureaucracy, administrative management, the concept of team spirit, systems and structural views, behavioral approach, motivational approach and management by objectives have been center stage in the debate. Henry Fayol (1951); Frederick Taylor (1911); MacGregor (1960); Elton Mayo (1946); Bernard and Simon (1940); Kreitner, (1995); as cited by Fonkeng and Tamajong (2009), believe that educational leaders are required to be cultured on various theoretical foundations of leadership to be able to influence leaders to graduate with the same skills. In addition to the above theoretical foundations of leadership, Burn's theory of transformational leadership has been considered as an overhaul of traditional approaches to current trends. This theory states that the leadership process is based on the mutual help of the leader and the subordinates for motivation and to increase their morale. His theory is believed to be consistent with present democratic norms, and most essentially as it emphasizes on the moral and educative nature of relationships between the leaders and the followers. Burn described transforming leaders as those who work to positively change followers to become leaders for the growth of the organization. To him, transforming leaders strive for cultural change in an organization, which is not the case with transactional leaders. Thus, transforming leaders are exemplary models who work for the team/group,

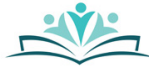


organization and for the community (Burns, 1978). Burn's transformational leadership is based on three themes, which are:

- Power and motive: this calls for the control of power since they are dealing with humans. To Burns, the purpose of power should be to uplift subordinates and customers, and not crushing them.

- Leadership as mutual purpose: transformational leaders are required: power should be used for a clear human purpose, and not for an individual purpose or to resolve self-interest.

- Transformational leadership as a moral attempt: these leaders are required to demonstrate the following qualities: humbleness, morality, excellent communication skills, positive attitude, forgiveness, peace-oriented, powerful presence, clear vision, focus, determination, patience, hopeful, inspirational... (Egli, 2019).

Burns also contends that Transformational leaders are of various types which are:

- Reformists: transforming a huge number of subordinates for high moral values.

- Intellectualists: using intellectual values to transform people.

- Revolutionists: leaders who sacrifice, and transform the whole aspect of a society.

- Charismatic or charming: role models.

The work of Burns was extended by Bernard M. Bass (1995), who explained the psychological mechanisms that underlie transformational and transactional leaderships. To him, transformational leadership could be measured based on the influence on and motivation of followers to perform in attaining organizational goals. He asserts that when followers feel trust, admiration, loyalty and respect for such leaders, they work harder than expected. Bass (1995) presents the qualities of a transformational leader as follows:

- Individualized considerations: responding to followers' personal needs via coaching, motivation, mentoring, empathy, support, and push for self-development and intrinsic motivation for task realization.

- Intellectual stimulation: considering follower's ideas in decision-making. This encourages creativity, learning and some degree of self-confidence by followers. It is however a high-level risk for the leader.
- Inspirational motivation: the extent to which the leaders communicate the vision and mission of the organization to followers determines their engagement. Transformational leaders communicate missions, and tasks with absolute optimism, and offers something more than just conventional gains to followers.

- Idealized influence: works as a role model, instills pride, high ethical behavior, respect and trust.

However, this theory was criticized for being more an idea than pragmatic. Some schools of taught slammed the theory for not being well suited for complex and emergency situations. (Bass \& Avolio, 1994a \& 1994b).

\section{Implications of the theory}

Leaders of small and medium sized educational enterprises are required to subscribe to this trend of action. This is justified by the fact that wealth creation can be a success only if transforming skills are possessed and demonstrated. Such leaders must have a sense of power and purpose, leadership and morals values which give high credibility and reputation to an enterprise, there by attracting wealth in other forms such as finances, more clients, partnership with big organizations, and individual donors, and experts. Leaders of these businesses are required to use their power with human purpose: skilled development, education and training of leaders. Using this power to intimidate others will yield no fruits. Nelson Mandela is a perfect example as he used his power for the growth of the South African society. And finally, these leaders are required to harnesses humility, patience, hopefulness, positive attitudes, so as attract responsible partners, more clients, and subsequently wealth creation in terms of reputation, values, finances, human relations, and logistics. But if these leadership skills are not demonstrated by higher education leaders in terms of administrative and teaching staff, graduates will not be able to have and use these skills for self-reliance in their private start-ups for wealth creation when employment with the government cannot be found.

\section{Methodology}

\section{Study Design and Instruments}

The study used a survey design which permitted the perfect management of a heavy population $(210$ respondents), and the use of an exhaustive 15-item 
carefully designed SWOT work sheet to collect data on the strength, weaknesses, opportunities and threats to these firms. This data also permitted us to ascertain the Link between transformational leadership skills and wealth creation, using the case of the Faculty of Education (the University of Yaoundé I). Secondary data was obtained through documentary reviews, with most documents accessed online.

Population: The population under study constitutes cohort graduates of between 2014-2019, of the Faculty of Education, The University of Yaoundé I, who own and run, or are former owners of small and medium-sized educational firms in and around university campuses in the city of Yaoundé.

Sampling methodology: these graduates were traced through the snowball technique, then grouped into clusters for easy data collection.
Data analysis technique: the data was analyzed with SWOT Analysis and Multiple Regression Analysis techniques.

\section{Results}

The SWOT analysis was used to analyze data collected and is written in full as:

SWOT: $\mathbf{S}=$ strength, $\mathbf{W}=$ weaknesses, $\mathbf{0}=$ Opportunities, $\mathbf{T}=$ Threats.

The objectives for using SWOT analysis in this study was firstly to verify the SWOT of the enterprises and secondly to find out if leadership is conscious, and has the capacity of carrying out a SWOT for their firms, so as to prepare a strategic plan of action for the growth of their firms. The SWOT Matrix (Table 1)presents a report on some 10 small and medium sized educational firms.

The SWOT matrix in Table 1 summarizes the responses provided by some enterprises in relation to leadership and wealth creation. Looking at this table, we realized that these enterprises possess very little strengths with regards to wealth creation and sustainable growth. These firms demonstrate heavy weaknesses, which are strongly tied to leadership issues, organization, and management. However, the enterprises are surrounded by golden opportunities, which strong leadership can transform to wealth. Added to these weaknesses are threats which can cause the firms to short down if leadership is not improved.
- $\quad$ Existence multiple funding opportunities by non-governmental organizations, government initiatives such as the recent presidential funding for graduates' start-ups.

- Leadership workshops organized by British Council \& business organizations.

- Strategic location of firm around university campus.

- A heavy population thirsty for knowledge.

- Existence of trained teaching staff.

\section{Threats.}

- What are the factors you consider as threats to wealth creation and the growth of your firm, given the leadership statusquo?

- Lack of operation license

- Illegal location.

- An increase in e-marketing

- Increase in ICT integration in the teachinglearning process.

- Poor organization.

- No strategic business plan.

- Weak leadership.

- Emergence of well-organized educational start-ups with e-strategies(marketing \& teaching). 


\section{Descriptive Statistics}

Table 2 shows the codes and gradients as to the Likert scale used on the questionnaires. The number 1 represents strong denial to the statement, whereas the number 2 represents normal denial. The number 3 represents normal acceptance, whereas the number 4 represents strongest acceptance.

Table 2. Likert scale Key

\begin{tabular}{|c|l|c|}
\hline \multicolumn{2}{|c|}{ KEY } & Gradient \\
\hline SDA & Strongly Disagree & 1 \\
\hline DA & Disagree & 2 \\
\hline A & Agree & 3 \\
\hline SA & Strongly Agree & 4 \\
\hline
\end{tabular}

Table 3. University teaching policy \& wealth creation plans in educational firms.

\begin{tabular}{|c|c|c|c|c|c|c|}
\hline No & Item & & SDA & DA & A & SA \\
\hline \multirow[b]{2}{*}{1} & \multirow{2}{*}{$\begin{array}{l}\text { The higher education policy } \\
\text { reforms in Cameroon has } \\
\text { established strong } \\
\text { orientations towards } \\
\text { entrepreneurships education } \\
\text { and wealth creation in } \\
\text { enterprises. }\end{array}$} & $f$ & 128 & 47 & 26 & 9 \\
\hline & & $\%$ & 61.0 & 22.4 & 12.4 & 4.2 \\
\hline \multirow[b]{2}{*}{2} & \multirow{2}{*}{$\begin{array}{l}\text { Higher education reforms } \\
\text { targets are quite specific with } \\
\text { regards to various domains. } \\
\text { This has specifically taken } \\
\text { care of the realities of the } \\
\text { educational industry. }\end{array}$} & $f$ & 139 & 46 & 24 & 0.5 \\
\hline & & $\%$ & 66.2 & 21.9 & 11.4 & 0.5 \\
\hline \multirow[b]{2}{*}{3} & \multirow{2}{*}{$\begin{array}{l}\text { Implementation of these } \\
\text { reforms are practiced in } \\
\text { faculty teachings }\end{array}$} & $f$ & 151 & 29 & 21 & 9 \\
\hline & & $\%$ & 71.9 & 13.8 & 10.0 & 4.3 \\
\hline
\end{tabular}

Table 4. Curriculum and transformational leadership.

\begin{tabular}{|c|c|c|c|c|c|c|}
\hline No & Item & & SDA & DA & A & SA \\
\hline \multirow{2}{*}{1} & \multirow{2}{*}{$\begin{array}{l}\text { Content design in terms of } \\
\text { conception guarantees } \\
\text { prospects for transformational } \\
\text { leadership skills in education. }\end{array}$} & $f$ & 202 & 8 & 0 & 0 \\
\hline & & $\%$ & 96.2 & 3.8 & 0 & 0 \\
\hline \multirow{2}{*}{2} & \multirow{2}{*}{$\begin{array}{l}\text { Content design in terms of } \\
\text { programs specialty is tailored } \\
\text { towards developing wealth } \\
\text { creations skills in learners. }\end{array}$} & $f$ & 186 & 24 & 0 & 0 \\
\hline & & $\%$ & 88.6 & 11.4 & 0 & 0 \\
\hline \multirow[b]{2}{*}{3} & \multirow{2}{*}{$\begin{array}{l}\text { Content is more practical than } \\
\text { theoretical and strongly rooted } \\
\text { in leadership theories and } \\
\text { practices. }\end{array}$} & $f$ & 180 & 22 & 8 & 0 \\
\hline & & $\%$ & 85.7 & 10.5 & 3.8 & 0 \\
\hline
\end{tabular}

Item 1 of table 4 indicates that a larger percentage of respondents making $96.2 \%$ strongly disagree on the fact that content conception guarantees prospects for transformational leadership skills. The rest $3.8 \%$ disagreed as well, whereas no respondent simply agreed or strongly agreed to this item as shown in columns A and SA. On its part, item 2 scored $88.6 \%$ and $11.4 \%$ strongly and simply disagreeing on the statement that content specialty is tailored to develop wealth creation skills. however, no respondent agreed or disagreed on this item as shown in columns $A$ and SA. In item 3 of the same table, $85.7 \%$ of respondents and $10.5 \%$ strongly disagreed and agreed respectively on the statement that the content is rooted in leadership theories and practice, whereas only $3.8 \%$ simply agreed on. The tendency illustrated by these statistics explains the predicted pattern that content dynamics in higher education are weak regarding transformational leadership and wealth creation. 
Table 5. Teaching-learning models and wealth creation.

\begin{tabular}{|c|l|c|c|c|c|c|}
\hline N0 & \multicolumn{1}{|c|}{ Item } & & SDA & DA & A & SA \\
\hline 1 & $\begin{array}{l}\text { Teaching-learning model is an } \\
\text { apprentice model or significantly } \\
\text { internship based }\end{array}$ & $f$ & 186 & 21 & 3 & 0 \\
\cline { 2 - 7 } 2 & $\%$ & 88.6 & 10.0 & 1.4 & 0 \\
\hline & $\begin{array}{l}\text { Industrial stakeholders significantly } \\
\text { participate in career orientation } \\
\text { workshops, and leadership } \\
\text { motivational discourses during the } \\
\text { degree program }\end{array}$ & $f$ & 199 & 11 & 0 & 0 \\
\cline { 2 - 7 } 3 & $\begin{array}{l}\text { Industrial stakeholders significantly } \\
\text { participate in faculty program } \\
\text { delivery through meaningful } \\
\text { internship training. }\end{array}$ & $f$ & 112 & 18 & 53 & 27 \\
\cline { 2 - 7 } & $\%$ & 53.3 & 8.6 & 25.2 & 12.9 \\
\hline
\end{tabular}

Table 6. The importance of entrepreneurial education.

\begin{tabular}{|c|c|c|c|c|c|c|}
\hline No & Item & & SDA & DA & A & SA \\
\hline \multirow{2}{*}{1} & \multirow{2}{*}{$\begin{array}{l}\text { Entrepreneurship courses are } \\
\text { obligatory in all the } \\
\text { departmental curricula. }\end{array}$} & $f$ & 210 & 0 & 0 & 0 \\
\hline & & $\%$ & 100.0 & 0 & 0 & 0 \\
\hline \multirow[b]{2}{*}{2} & \multirow{2}{*}{$\begin{array}{l}\text { The dose of entrepreneurship } \\
\text { courses are significant in terms } \\
\text { of start-ups, organizational } \\
\text { leadership, wealth creation, and } \\
\text { business management. }\end{array}$} & $f$ & 193 & 17 & 0 & 0 \\
\hline & & $\%$ & 91.9 & 8.1 & 0 & 0 \\
\hline \multirow{2}{*}{3} & \multirow{2}{*}{$\begin{array}{l}\text { Volunteerism education is being } \\
\text { mainstreamed in the curriculum. } \\
\text { This is a push factor for learners } \\
\text { to acquire relevant field } \\
\text { experiences in general, and } \\
\text { leadership skills in particular. }\end{array}$} & $f$ & 210 & 0 & 0 & 0 \\
\hline & & $\%$ & 100.0 & 0 & 0 & 0 \\
\hline
\end{tabular}

Item 1 of table 5 indicates that the teaching models used in higher education are not apprenticeship-based as strongly disagreed by $88.6 \%$ of the respondents. $10 \%$ equally disagreed, whereas only $1.4 \%$ agreed. $94.8 \%$ of respondents strongly disagreed with the statement that industrial stakeholders significantly participate in career orientation workshops, and leadership motivational discourses during the degree program. The survey revlealed that $5.2 \%$ disagreed as well, while no respondents agreed or strongly agreed. Looking at item 3, we noted that $53.3 \%$ and $8.6 \%$ of the respondents strongly agreed and agreed respectively on the university-industry partnership in teaching. However, $25.2 \%$ agreed, while only $12.9 \%$ strongly agreed. Judging from the observation, we infer that the bulk of the respondents have underscored that teaching methods are not geared towards developing skills for transformational leadership and wealth creation.This has a strong link with the problem under investigation as entrepreneurship skills are required to be transmit ted via hands-on approaches to familiarizelearners with real world circumstances.

Item 1 on table 6 shows that all respondents strongly disagree with the fact that entrepreneurship courses are transversal in all departments. Unlike in item 1, item 2 indicates a high percentage (91.9) of respondents who disagree with the statement that the dose of entrepreneurship courses is significant in terms of start-ups, organizational leadership, wealth creation, and business management. The remaining $8.1 \%$ simply disagreed as well, whereas, no respondent agreed or strongly agreed as indicated by the " 0 " in the two columns in the right. For item 3 all respondents disagree that volunteerism education is being mainstreamed in the curriculum. However, the observation from these statistics explains the inference that entrepreneurship education is offered the least important place in the education and training of higher education graduates. This may explain why they lack skills to successfully run their businesses. 
Table 7. Distribution of respondents based on wealth creation skills.

\begin{tabular}{|c|c|c|c|c|c|c|}
\hline NO & Item & & SDA & DA & A & SA \\
\hline \multirow[b]{2}{*}{1} & \multirow{2}{*}{$\begin{array}{l}\text { My firm has a strategic business } \\
\text { plan which permits us to obtain } \\
\text { significant funding from donors. }\end{array}$} & $f$ & 124 & 47 & 20 & 19 \\
\hline & & $\%$ & 59.9 & 22.4 & 9.5 & 9.0 \\
\hline \multirow[b]{2}{*}{2} & \multirow{2}{*}{$\begin{array}{l}\text { My firm has entered into } \\
\text { meaningful partnerships that } \\
\text { allows essential interactions } \\
\text { involving financial exchange, } \\
\text { training exchange, scholarships, } \\
\text { policy issues, leadership expertise } \\
\text { and growth tactics. }\end{array}$} & $f$ & 175 & 32 & 3 & 0 \\
\hline & & $\%$ & 83.3 & 15.2 & 1.4 & 0 \\
\hline \multirow[b]{2}{*}{3} & \multirow{2}{*}{$\begin{array}{l}\text { Our enterprise is growing } \\
\text { sustainably in terms of reputation } \\
\text { and credibility, candidates, human } \\
\text { resources, logistics, and financial } \\
\text { capital }\end{array}$} & $f$ & 174 & 26 & 10 & 0 \\
\hline & & $\%$ & 82.9 & 12.4 & 4.8 & 0 \\
\hline
\end{tabular}

Item 1 on table 7 probes into the availability of strategic business plan which permits businesses to obtain significant funding from donors. Field statistics show that $59.9 \%$ and $22.4 \%$ of respondents strongly disagree and disagree respectively. However, 9.5\% agreed, whereas $9.0 \%$ strongly agreed. Looking at statistics from item 2 , we noted that $83.3 \%$ of the respondents strongly disagreed that their firm has entered into meaningful partnerships that allows essential interactions involving financial exchange, training exchange, scholarships, policy issues, leadership expertise and growth tactics. The data also show that $15.2 \%$ adhered to this statement, while only $1.4 \%$ agreed. Data in item 3 indicates that $82.9 \%$ of the sample strongly disagreed that their firms were growing sustainably, while $12.4 \%$ disagreed. On the other hand, an extremely small portion $4.8 \%$ simple agreed, whereas no respondent strongly disagreed. The meaning that can be made out of these data may explain the struggling circumstance which these firms experience. They struggle to thrive, as most even closed down before 5 years.

\section{Inferential Statistics}

To test the hypotheses, the data were analyzed using a multiple regression anlaysis to confirm a correlaction between several variables captured in the survey data. The data were then analyzed using ANOVA methods to identify the relationship between the variables.

\section{Multiple regression Analysis.}

Table 8 suggests that there is an extremely high correlation $\mathrm{R}(0,996)$ between transformational leadership and wealth creation in educational enterprises by graduates. This high correlation coefficient signify that transformational leadership skill is highly significant for any good performance in educational firms. Otherwise, the mal-performances observed in educational enterprises around the city of Yaoundé is strongly linked to poor leadership skills by it owners. This finding is reinforced by another key statistics on the same table 8 , R-square or $\mathrm{R}^{2}$ $(0,992)$ shows indicating that $99,2 \%$ of poor wealth creation in educational firms can be explained by lapses in transformational leadership skills, whereas, the remaining $0.8 \%$ is explained by factors out of the model. On a more specific level, table 8 equally suggests that R-adjusted (.992) indicates a very good variable-fit of all sub variables. Hence, higher education policy, transformational leadership curriculum, wealth cre-ation teaching-learning models, modes of mainstream-ing entrepreneurship education in faculty teaching significantly fit and strongly predicts wealth creation in educational firms by graduates. This mean that worry-ing lapses exist at specific variable levels of university training (see tables $3,4,5$, and 6).

Table 8. Model summary

\begin{tabular}{cc|c|c|c}
\hline Model & R & $\begin{array}{c}\text { R- } \\
\text { square }\end{array}$ & $\begin{array}{c}\text { Adjusted } \\
\text { R-square }\end{array}$ & $\begin{array}{c}\text { Std. Error } \\
\text { of Estimate }\end{array}$ \\
\hline 1 & $.996 a$ & .992 & .992 & .16640 \\
\hline
\end{tabular}

a. Predictors: (Constant), higher education policy model towards wealth creation plans, transformational leadership curriculum, wealth creation teaching-learning models, modes of mainstreaming entrepreneurship education in faculty teaching. 
Table 9: ANOVA.

\begin{tabular}{ll|c|c|c|c|c}
\hline & & Sum of & & & & \\
Model & squares & Df & Mean square & F & Sig. \\
\hline \multirow{2}{*}{1} & Regression & 694.781 & 4 & 173.695 & 6273.073 & $.000 \mathrm{~b}$ \\
\cline { 2 - 7 } & Residual & 5.676 & 205 & .028 & & \\
\cline { 2 - 8 } & Total & 700.457 & 209 & & & \\
\hline
\end{tabular}

a. Dependent Variable: wealth creation in educational firms by graduates.

b. Predictors: (Constant), higher education policy model towards wealth creation plans, transformational leadership curriculum, wealth creation teaching-learning models, mainstreaming entrepreneurship education in faculty teaching.

Table 9 shows that the overall regression model is a good fit for the data. This table indicates that transformational leadership skills statistically significantly predicts wealth creation in educational firms by graduates. $\left(\mathrm{F}_{(4,205)}=6,273.073, \mathrm{p}<0.0005\right)$. This means that the poor wealth creation situation in educational firms by graduates is highly explained by the lapses in transformational leadership skills embed by faculty teachings.

The scatter-plot graph (Figure 1) demonstrates a significant concentration points around the straight line. This indicates a significant relationship between transformational leadership skills and wealth creation. The correlation coefficient is 0.957 , approaches 1 , therefore strongly supports the hypothesis.

\section{Discussion of Results}

Graduate unemployment has reached preoccupying levels in Cameroon, thus appealing for every bit of reflection on measures to tackle the problem. It is for this reason that the surroundings of educational milieus are filled with graduates operating small and medium sized enterprises. This study initially set out to investigate the extent to which graduates of the Faculty of education are equipped with transformational leaderships skills, for them to thrive in these enterprises. In this light, 210 firms were sampled for questioning, whereas some went through a SWOT analysis. This permitted the researcher to bring out the strengths and weaknesses of these enterprises, and to determine the degree of prediction on wealth creation by transformational leadership lapses in the enterprises.

This was demonstrated by the results obtained after running the multiple regression test $\left(\mathrm{F}_{(4,205}\right)=$ $\left.6,273.073, p<0.0005, R^{2}=0.992\right)$. This test permitted us to confirm all four predictors: higher education policy model towards wealth creation plans, transformational leadership curriculum, wealth creation teaching-learning models, modes of mainstreaming entrepreneurship education in faculty teaching as statistically significant towards wealth creation. This is justified by descriptive statistics, where respondents strongly disagreed with the fact that higher education policy reforms in Cameroon have established strong orientations towards entrepreneurships education and wealth creation in enterprises. As a matter of fact, $61 \%$ strongly disagree, while $22.4 \%$ also disagreed, thus aligning to this thesis. The 2016 report by the National Institute of Statistics held that a key strategy to fight the premature collapsing of small and medium sized enterprises is establishing strong human capital training policies. To Rowe (ibid), the leadership of enterprises must receive essential skills for the task at hand. 
Moreover, $66.2 \%$ and $21.9 \%$ strongly disagreed and disagreed to the statement that education reforms targets are quite specific with regards to various domains. This has specifically taken care of the realities of the educational industry. The observation in the Faculty of Education indicates the absence of transformational leadership courses as obligatory teaching units, as well as the absence of a specific entrepreneurship content. Statistics indicates a $100 \%$ of respondents strongly disagreeing to the presence of domain specialization in leadership courses, and the presence and an obligatory leadership and entrepreneurship education. This position is supported by the European document on entrepreneurship leadership in education recommends high level mainstreaming of this type of education in educational policy, curriculum and teaching approaches.

The world document for 2019 on leadership which makes mention of the need for intellectual skills as critical to the success of educational leaders. In this light, Bass \& Bass (2009) talk of intellectual stimulation as a key quality of transformational leaders. These authors explained that transforming leaders is a great deal of having the intellectual capacity to get followers into creativity and innovation. However, this cannot be done without having acquired relevant leadership skills. Things become more serious as $91.9 \%$ of respondents strongly disagreed that the dose of entrepreneurship courses are significant in terms of start-ups, organizational leadership, wealth creation, and business management. This is followed by $100 \%$ of respondents disagreeing that voluntarism is being encouraged during training. The European entrepreneurship leadership in education posits that strong educational leaders cannot be produced when field acquaintances are excluded during training. The document upholds key modes like meaningful partnerships between faculty and industry in curriculum design and delivery, and a significant mainstreaming of volunteerism culture in our system.

The degree of weaknesses presented by these enterprises is a vivid indicator of the absence of transformational leadership skills in these firms. These weaknesses range from limited infrastructure to no partnerships, lack of a strategic plan, but to name a few. In addition to this, a close look at the at the threats such as Lack of operation license, Illegal location, an increase in e-marketing, increase in ICT integration in the teaching-learning process, poor organization, no strategic business plan, weak leadership strongly justify the premature shoot-down of these businesses. These weakesses are visible in wealth creation statistics as
$82.9 \%$ of respondents strongly disagree their enter-prises are growing sustainably in terms of reputation and credibility, candidates, human resources, logistics, and financial capital. This falls squarely with the re-formist and idealized qualities of a transformational leader by Bass (1995), who thinks that wealth creation means transforming every aspect of the organization.

However, when we look at the unexploited opportunities which could help sustain these firms, we conclude that there is need for strong transformational leadership skill for these owners of the businesses. Some opportunities include: existence of multiple funding opportunities by non-governmental organizations, and some government initiatives such as the recent presidential funding for graduates' start-ups, leadership workshops organized by the British council, and business organizations, strategic location of the businesses around the university campus, a heavy population thirsty for knowledge, and existence of trained teaching staff. This means that the need for transformational leadership is imperative so as to transform these opportunities into strength towards wealth creation in these firms.

\section{Conclusion}

This study set out to investigate the bearing of transformational leadership education in universities on graduates' wealth creation. The wealth creation skills acquired by graduates will be a signal as to whether their business start-ups succeed or fail. Possession and use of these skills in small and medium sized enterprises opened by graduates of the university of Yaoundé I are therefore determinants of the lifespan, growth and profitability of these businesses. Based on SWOT and regression tests, findings revealed lapses in programs, government policy and teachings methods. Given the grim picture of employment in the country, it will be high time transformational leadership skills are embedded in higher education curricula as a whole to equip graduates with skills that can enable them have a smooth transition to the volatile labor market and to keep afloat in the tense competition therein.

Another concluding note in this paper is in this paraphrase by Victor Hugo in Axford (1969), that nothing is truer than the power of an idea when its time has come. But that idea must be borne by people with vision, leadership and moral fortitude to recognize the validity of the idea andinstitutionalize it. It is therefore time transformational leadership education 
gained its place among the professions, especially within the profession of education in Cameroon. It has too long been peripheral and marginal. Government and other education stakeholders must start thinking of how this can be woven into the educational fabric of our country, so that it can play its own role; that of providing sustainable self-employment to graduates when government fails to.

\section{Recommendations}

The following recommendations could greatly lead to improvements in the quality of education and catalyze wealth creation for graduates.

There should be reinforcement of policy implementation in higher education through commensurate quality control measures by putting in place a higher education planning team who should seek to understand the needs of all stakeholders in the higher education domain. This team will be in charge of carrying out a need analyses of all stakeholders in higher education periodically in order to inform curriculum designers. The team will advise the minister of higher education on issues of curriculum reforms by producing periodic reports on evolving global trends in the higher education arena, so as to address quality and respond to the demands of the 21th century knowledge economy. This will partly solve Cameroon's pressing need of producing more market ready graduates who will not fall into the unemployment trap.

Secondly, promotion of entrepreneurship education should be one of the topmost education reforms in the country so as to encourage the creation of enterprises which can absorb the growing number of unemployed graduates. Final year students should be placed in enterprises for internships or volunteerism to develop work experience as required prerequisites for finding first graduate employment or creating one. Finally, with regards to government policy, there is need for an in-crease in public spending on higher education in terms of updating dilapidated infrastructure such as labo-ratories, and installing modern technological and ICT gadgets in order to professionalize teaching and evalua-tion in a bid to enhance practical knowledge acquisition which is indispensable in wealth creation.

\section{Suggestions for further research}

The following suggestions for further research are made based on the believe that no research work can be all encompassing and that research is continuous. It will therefore be proper to open up and cast a glance into future research interests which could emanate from this one or build on it. The same research topic could be carried out with a larger population and sample, covering more African countries selected for comparability and best practice. Other research interest could focus on the comparability of private and public universities in terms of graduate employability in Cameroon. Another study could also focus on the demand and supply of entrepreneurship education and the effects on economic growth. Finally, these suggested areas of research could be carried out for longer peri-ods of experimentation and with larger sample sizes to enhance the degree of reliability. 


\section{References}

Axford, R. W. (1969). Adult Education: The Open Door. Scranton, PA: International Textbook Company.

Bass, B. M. (1995). Theory of transformational leadership redux. The Leadership Quarterly, 6(4), 463-478.

Bass, B. M., \& Avolio, B. J. (Eds.). (1994a). Improving organizational effectiveness through transformational leadership. Sage.

Bass, B. M., \& Avolio, B. J. (1994b). Transformational leadership and organizational culture. The International Journal of Public Administration, 17(3-4), 541-554.

Bass, B. M., \& Bass Bernard, M. (1985). Leadership and performance beyond expectations.

Bass, B. M., \& Bass, R. (2009). The Bass handbook of leadership: Theory, research, and managerial applications. Simon and Schuster.

Burns, J.M. (1978). Leadership. New York. Harper \& Row.

Bush, T., \& Glover, D. (2012). Distributed leadership in action: Leading high-performing leadership teams in English schools. School leadership \& management, 32(1), 21-36.

Cameroon. (2010). GESP Growth and Employment Strategy Paper: Reference framework for Government action over the period 2010-2020. Washington DC, International Monetary Fund.

Davies, B. J., \& Davies, B. (2004). Strategic leadership. School Leadership \& Management, 24(1), 29-38.

Davies, B., \& Ellison, L. (1997). School leadership for the 21st century: A competency and knowledge approach. Psychology Press.
Egli, R. R. (2019). Impact of transformational leadership on employees and company performance. In European Scientific Conference of Doctoral Students, (p. 39). Brno, November 28, 2019.

European Commission. (2013). Entrepreneurship education: A guide for educators. Brussels: European Commission-DG Enterprise \& Industry.

Farrant, J. S. (1980). Principles and practice of education (New Edition). Hong Kong: Longman.

Fonkeng, E. G., \& Tamajong, E. V. (2009). Secondary school administration and principalship. Yaounde: Presses Universitaires d'Afrique.

National Institute of Statistics (2019). Report on small and medium sized enterprises. Business Cameroon.

NGU, S. W., \& Teneng, P. P. (2020). Unlocking graduates' employability: The Case of technical high school graduates of the Diamaré Division, Far North Region, Cameroon. American Journal of Educational Research, 8(9), 705-717.

Odumeru, J. A., \& Ogbonna, I. G. (2013). Transformational vs. transactional leadership theories: Evidence in literature. International review of management and business research, 2(2), 355.

Rowe, W. G. (2001). Creating wealth in organizations: The role of strategic leadership. Academy of Management Perspectives, 15(1), 81-94.

World Bank (2019). Skills stability. World Economic Forum. A

Yukl, G. (1994). Leadership in organizations (3rd ed.). Toronto: Prentice Hall.

\section{Author}

Patience P. Teneng (patience.bame@yahoo.com) is a Lecturer in the Department of Curriculum \& Evaluation at University of Yaoundé, Yaoundé, Cameroon. 